\title{
Induction of apoptosis and necrosis in leukemic cells by purified IgG of blood serum of mice which were fed with cattle brain for a long time
}

\author{
M.R. Kozak, V.V. Vlizlo, Y.Y. Kit, R.S. Stoika \\ Institute of Animal Biology UAAS \\ Vasyl' Stus street, 38, Lviv, 79034, Ukraine \\ Institute of Cell Biology, NAS of Ukraine \\ Drahomanov St. 14/16, Lviv, 79005, Ukraine \\ inenbiol@mail.lviv.ua
}

\begin{abstract}
IgG preparations of mice under study were tested for their ability to induce death of cells of L1210 line of murine leukemia. The highest level of cytotoxic activity was found at affecting cells with IgG of mice that were additionally fed with cattle brain. It was shown that the test cells were dying by both apoptosis (typical signs are destruction of DNA, revealed by the method of DNA-comets, condensation and fragmentation of chromatin, discovered by fluorescent microscopy of cells, stained with Hoechst 33342) and necrosis. The latter was estimated taking into account the level of lactate dehydrogenase activity, which appeared in cultural medium of 21210 cells, and by light microscopy after cell staining according to Romanovsky-Gimza.
\end{abstract}

Keywords: ration, immunoglobulins, cytotoxic activity, apoptosis, necrosis

Introduction. Transmissible spongiform encephalopathies (TSE) belong to the group of extremely dangerous neurodegenerative diseases, affecting both different species of animals and humans (Creutzfeldt-Jakob disease). These diseases are characterized by the presence of spongiform neoplasms in the affected brain. Clarification of reasons of TSE appearance involves two concepts - prion and autoimmune ones [1-3]. The former is based on the participation of prions in the development of spongiform neoplasms. This disease is considered to be caused in brain by the

(C) M.R. KOZAK, V.V. VLIZLO, Y.Y. KIT, R.S. STOIKA, 2008 accumulation of PrPsc protein with changed conformation of its molecule [4-7]. This concept is currently considered the most valid, however, it can not explain all the known cases of TSE appearance.

Autoimmune concept is based on the fact that spongiform neoplasms in the brain of sick animals are the result of autoimmune reaction $[8,9]$. The presence of auto-antibodies of brain in blood and cerebrospinal fluid of animals with TSE and people with Creutzfeldt-Jakob disease, evidence in favour of the latter concept [10]. The mechanisms of induction of autoimmune processes at TSE are yet to be studied. The appearance of auto-antibodies to brain proteins is 
believed to be the consequence of molecular mimicry of some foreign antigens, which enter the organism via consumption of infected food by animals [11]. It is possible that lasting consumption of some food antigens may also result in autoimmune disorders which cause TSE in animals in certain conditions. One of the indicators of autoimmune processes in the mammalian organism may be the level of cytotoxic activity of immunoglobulins of blood plasma $[12,13]$.

The aim of current work was to study cytotoxic activity of immunoglobiluns of $\mathrm{G}$ class of blood serum of mice, fed with cattle brain, compared to those, fed with meat-and-bone meal or soy flour.

Materials and Methods. Investigation was performed on five groups of white non-linear mice. Each group consisted of eight animals. Daily ration of one animal of control group (K) included $8 \mathrm{~g}$ of fruit, 2 $\mathrm{g}$ of bread, $3 \mathrm{~g}$ of wheat cereal, $2 \mathrm{~g}$ of hay, $1 \mathrm{~g}$ of root crops (carrots and beets), $0.5 \mathrm{~g}$ of sunflower seeds, and water without limitations. The first investigated group (M) was additionally fed cattle brain (50 mg of brain tissue per one mouse), the second one $(\mathrm{M}+\mathrm{B})-25 \mathrm{mg}$ of brain and $25 \mathrm{mg}$ of meat-and-bone meal (Kupyansky Vetsanzavod, Ukraine), the third one (B) - $50 \mathrm{mg}$ of meat-and bone meals, and the fourth (C) - $50 \mathrm{mg}$ of soy flour. The experiment lasted for one year.

IgG preparations were obtained from the general fraction of immunoglobulins after three-time precipitation of proteins of blood serum with ammonium sulphate and affinity chromatography on the column, filled with protein G-agarose (Sigma, USA) [13]. Protein concentration in the obtained preparations was determined at the wavelength of 280 nm using spectrophotometer (NanoDrop Technologies, USA). The purity of preparations was defined by electrophoresis in $12 \%$ polyacrylamide gel (PAAG) in the presence of $0.1 \%$ sodium dodecyl sulphate [15].

To study cytotoxic activity of IgG preparations, the cells of L1210 line of mice leukaemia were used (Collection of Cell Cultures of the Institute of Experimental Pathology, Oncology, and Radiobiology named after R.Ye. Kavetsky, NAS of Ukraine). Cells were incubated in the Igla medium, modified by Dulbecco (Sigma Chem. Co, USA) in the presence of $10 \%$ of embryonic serum of cattle (Sigma Chem. Co), and $50 \mu \mathrm{g} / \mathrm{ml}$ of gentamycin (Sigma Chem. Co).
Cells of L1210 (500 thousand/ml) were incubated with IgG preparations (final concentration of $2 \mu \mathrm{g} / \mathrm{ml}$ ) for 24 and 48 hours. The amounts of living and dead cells were calculated after their staining with $0.1 \%$ aqueous solution of trypan blue. At these conditions, living cells were not stained [16]. The vitality index (VI) of cells was calculated according to the formula: $\mathrm{VI}=\mathrm{O} / \mathrm{C} \cdot 100 \%$, where $\mathrm{O}$ - amount of living cells after the effect of IgG; $\mathrm{C}$ - amount of living cells in the culture. The cytotoxicity index (CI) was calculated according to the formula: $\mathrm{CI}=\mathrm{O} / \mathrm{C} \cdot 100 \%$, where $\mathrm{O}-$ amount of dead cells after the effect of IgG; $\mathrm{C}$ - amount of dead cells in the culture.

The state of chromatin in the nuclei of cells was determined after their staining with fluorescent Hoechst 33342 (Sigma) [17]. The morphology of cells was analyzed after their staining according to Romanovsky-Gimza [18].

DNA fragmentation was investigated by the method of microelectrophoresis in agarose gel [19]. To visualize DNA-comets, electrophoregrams were stained with ethidium bromide and photographed under MickMEd-12 microscope (LOMO, RF) in ultraviolet light.

ELISA. DNA of calf thymus (Sigma) in the concentration of $10 \mu \mathrm{g} / \mathrm{ml}$ was absorbed onto 96-cell plate (SARSTEDT, USA) for 18 hours at $4^{\circ} \mathrm{C}$, washed with $1 \%$ BSA in PBS, added $\operatorname{IgG}(0.02 \mathrm{mg} / \mathrm{ml})$, and incubated $\left(2\right.$ hours, $\left.37^{\circ} \mathrm{C}\right)$. Then it was incubated with secondary anti-murine antibodies, conjugated with horse radish peroxidase (Amersham Life Sciences, UK) for 1 hour at $37^{\circ} \mathrm{C}$ with subsequent washing with PBS, containing twin-20. 3.3'-diaminobenzidine (Sigma) was used as a chromogen. Absorption was measured at $492 \mathrm{~nm}$ using spectrophotometer (NanoDrop Technologies).

The activity of lactate dehydrogenase (LDG) in the cultural medium was determined by the method described in [20]. Average value of $M$ and average error $m$ were calculated for all the experiments, repeated three times. The reliability level of results obtained was defined with Microsoft Excel 5.0 calculating Student's coefficient. If $\mathrm{p} \leq 0.05$, changes in indicators were considered reliable.

Results and Discussion. We used 40 samples of blood serum of mice fed with different rations for a year 


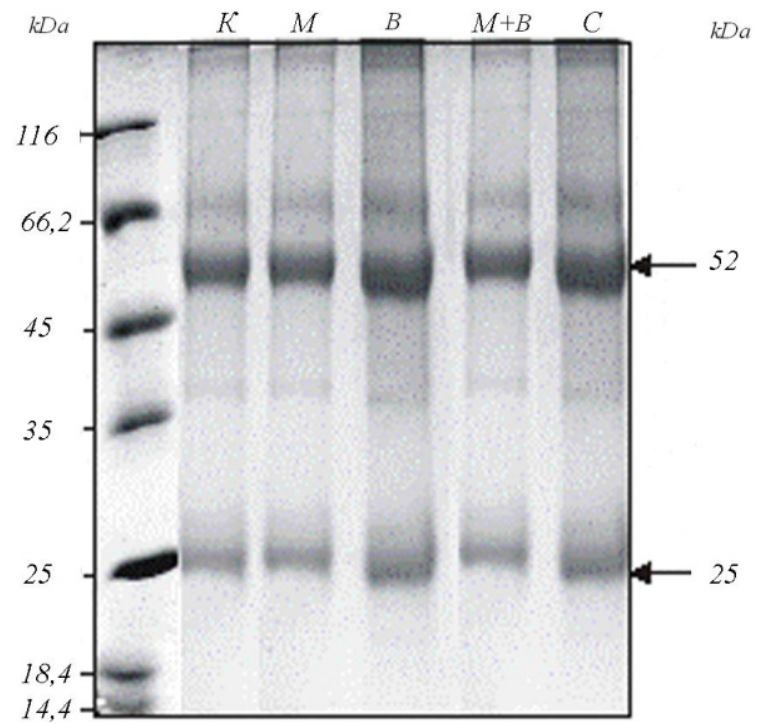

Fig. 1. Electrophoresis in $12 \%$ PAAG in the presence of $0.1 \%$ sodium dodecyl sulfate of IgG preparations purified from blood serum of mice by affinity chromatography on protein G-agarose: $K$ - IgG of blood serum of mice of control group; $M-\operatorname{IgG}$ of blood serum of mice additionally fed with cattle brain; $M+B-\operatorname{IgG}$ of blood serum of mice additionally fed with cattle brain and meat-and-bone meal $(1: 1) ; B$ - IgG of blood serum of mice additionally fed with meat-and-bone meal; $C$ - IgG of blood serum of mice additionally fed with soy flour

(see Materials and Methods). Electrophoretic analysis of IgG preparations, purified by affinity chromatography on protein G-agarose, showed that the main constituent of proteins of extracted fractions is polypeptides with molecular weight of 52 and $27 \mathrm{kDa}$, which correspond to heavy and light IgG chains of mice (Fig.1). Obtained IgG preparations were then used to study their cytotoxic activity. L1210 line of leukemic B-lymphocytes of mice was selected as a cellular test system.

The first stage of investigation was to analyse the influence of IgG preparations of formed groups of animals on the growth of L1210 line cells in vitro. Cytotoxic effect of IgG was determined by the dynamics of cell number after 24 and 48 hours of their culturing. IgG preparations were revealed to inhibit proliferation of L1210 cells at the $24^{\text {th }}$ hour of their action due to the following increase in their activity: $\mathrm{B}$ $>\mathrm{K}>\mathrm{M}>\mathrm{M}+\mathrm{B}>\mathrm{C}$ (Fig. 2). At the $48^{\text {th }}$ hour of cell incubation, the highest cytotoxic activity was demonstrated by $\mathrm{IgG}$ of control group of animals

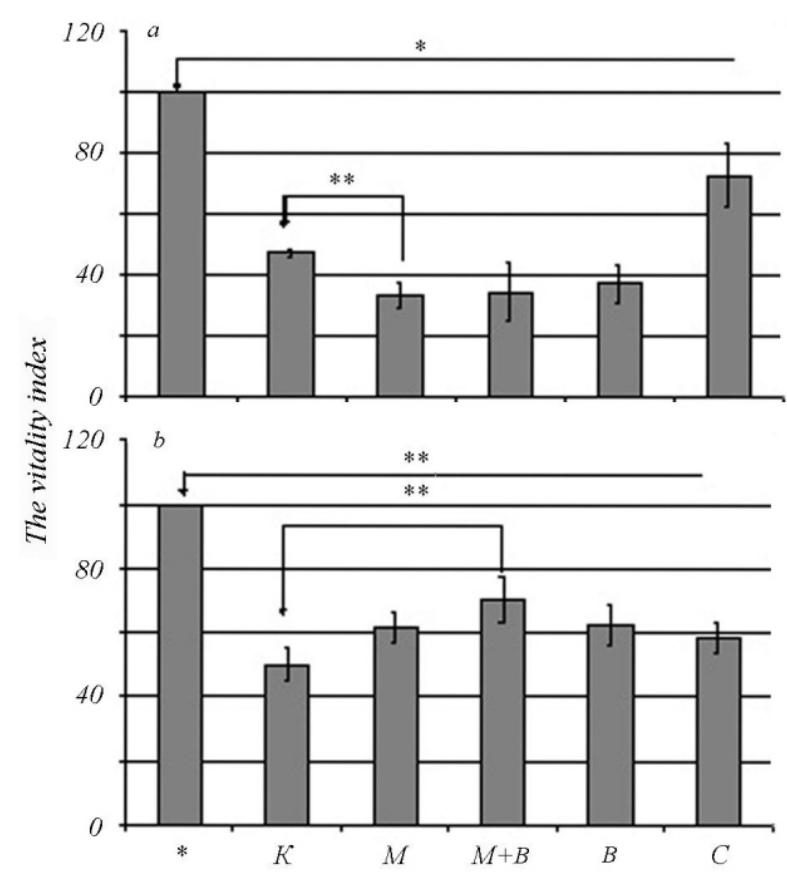

Fig. 2. Effect of IgG preparations of blood serum of mice on the vitality index (VI) of L1210 line cells: VI $=\mathrm{O} / \mathrm{C} \cdot 100 \%$, where $O$ number of living cells after $\operatorname{IgG}$ action; $C$-number of living cells in the culture; $a-24$ hours of cell incubating with IgG; $b-48$ hours of cell incubating with $\operatorname{IgG} ; K, M, M+B, B, C-$ see Fig. 1 ; * $\leq 0.05$; $* * \mathrm{p} \leq 0.01$

which inhibited the growth of L1210 cells in vitro almost twice.

The next stage was to study cytotoxic features of obtained IgG preparations. Cytotoxic effect of these preparations was determined at the $24^{\text {th }}$ and $48^{\text {th }}$ hours of incubation of cells according to the ration between living and dead cells. IgG of experimental groups of animals were revealed to differ in the ability to induce the death of L1210 line cells in vitro. Fig. 3 shows that cytotoxic activity of IgG preparations of different experimental groups of animals is considerably dependent on the duration of action of these preparations towards target cells. In case of 24-hour effect of IgG of animals that were additionally fed with cattle brain, CI was equal $200 \%$, and in case of 48 -hour effect $-370 \%$. At the same time, control animals that were fed with standard ration, showed much less increase of CI (24 hours $-152 \%$, 48 hours - 222\%). Animal feeding with meat-and-bone meal or soy flour resulted in gradual CI decrease, and the addition of 


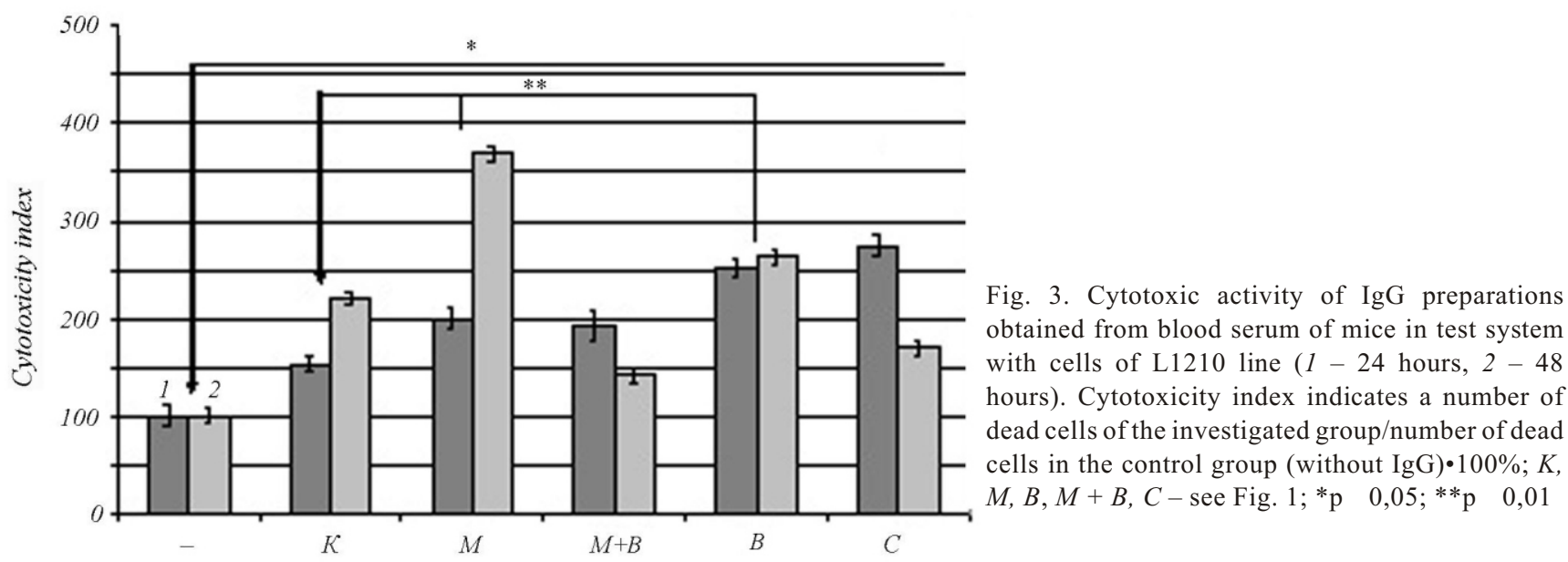

meat-and-bone meal to cattle brain removed this dependence.

Results obtained allow concluding that IgG of blood serum of mice, fed with different rations, induce the death of L1210 line cells of murine leukemia. The best cytotoxic effect was revealed at 48 -hour affecting these cells with IgG of mice whose ration was supplemented with cattle brain.

Death of cells in the organism is known to occur due to two main processes - apoptosis and necrosis [20]. Apoptotic and necrotic cells differ in their morphological and biochemical parameters. The former are characterized by condensation and fragmentation of nuclear chromatin, disorder in functions of mitochondria, expression of specific apoptotic protein, in particular, proteolytic enzymes caspases, shrinkage of plasma membrane, and formation of apoptotic bodies. Necrotic cells are specific for swelling of both cells and some organelles, breaking of plasma membrane, which results in outflow of cytoplasmic enzymes into the extracellular space $[21,22]$.

We used two characteristic features of apoptosis condensation and fragmentation of nuclear chromatin, were determined by cell staining with fluorescent Hoechst 33342 and by the method of DNA-comets, detecting fragmented nuclear DNA via electrophoresis (Fig. 4). Cell incubation with investigated IgG preparations revealed a significant increase in the number of cells with fragmented chromatin (Fig. 4). The only exception was IgG preparation of animals that were additionally fed with soy flour, where we found even some decrease in the amount of cells with damaged DNA.

Therefore, IgG preparations, purified from the blood serum of mice fed with various rations, differed in the ability to induce fragmentation of nuclear chromatin in L1210 line cells in vitro. The character of that fragmentation shows that the most probable cause of cell death was apoptosis. An important indicator of autoimmune processes in mammalian organism is the level of antibodies against two-chain DNA (anti-DNA antibodies) in blood serum [12]. To determine the level of anti-DNA antibodies in IgG preparations, purified from blood serum of animals, ELISA method was used. Obtained preparations of immunoglobulins of $\mathrm{G}$ class of experimental animals were revealed to contain 2-2.5 times higher amount of antibodies to thymus DNA comparing with IgG of control group. The highest level of antibodies to DNA was observed in IgG preparations from mice, fed with meat-and-bone meal supplemented with cattle brain (Fig. 5). Thus, considerable increase in the level of anti-DNA antibodies in IgG preparations extracted from blood serum of animals that were fed with cattle brain, evidences to possible autoimmune disorders in the organism of such mice.

To check whether investigated IgG can also induce necrosis of some cells, the activity of LDH was also determined in the cultural medium. This feature is specific for necrotic cells due to disorder of their plasma membrane and outflow of cytoplasmic enzymes into extracellular space. The data presented in Fig. 6 demonstrate that IgG preparations obtained from blood serum of animals which were additionally fed with 

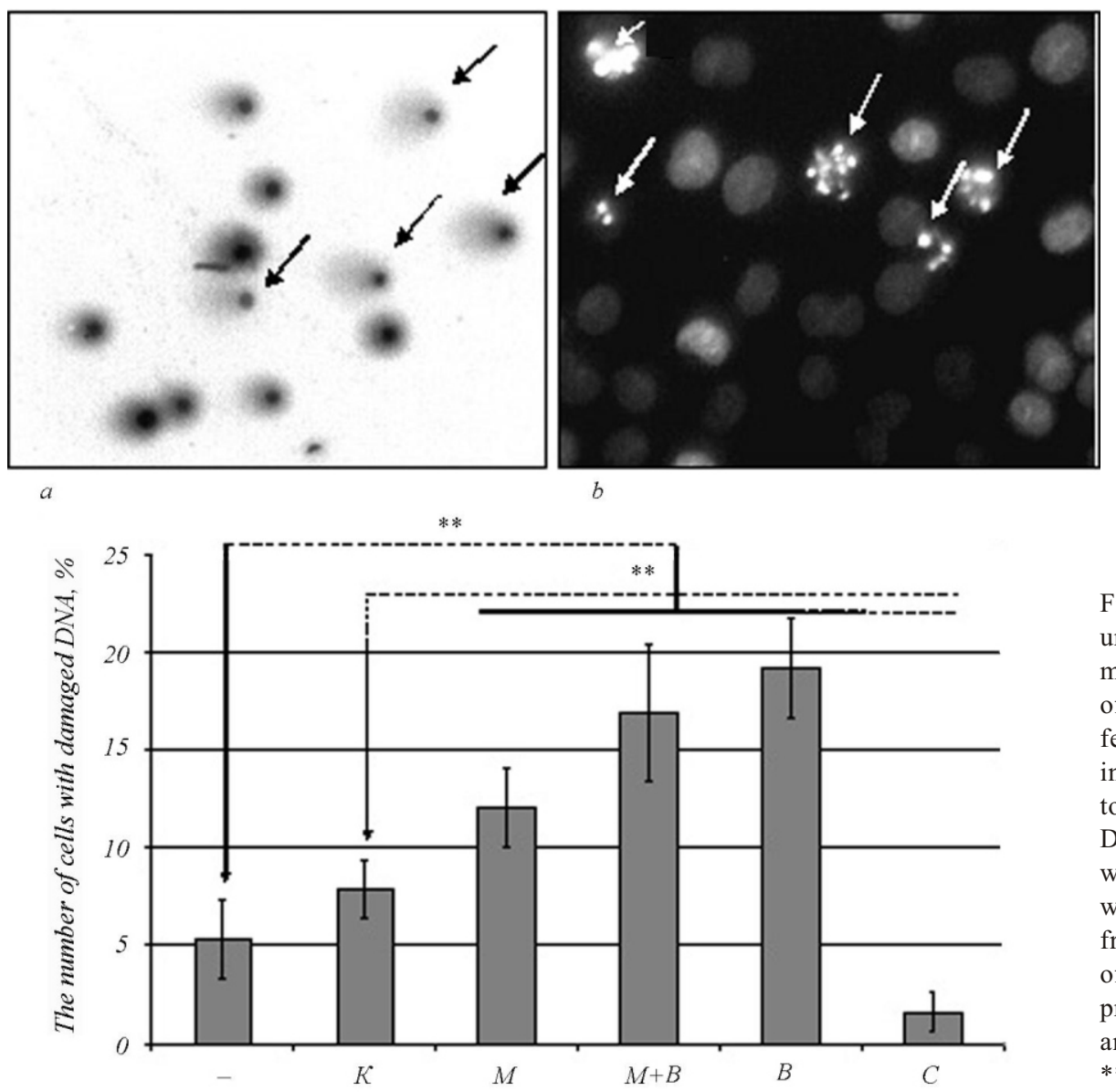

Fig. 4. Apoptosis of cells of L1210 line under the influence of IgG preparations of mice; $a$ - electrophoretic pattern of cells of L1210 line at the effect of IgG of mice fed with meat-and-bone meal (arrows indicate a formation of DNA-comets due to the appearance of low-molecular DNA); $b$ - staining of cells of L1210 line with Hoechst 33342 (arrows indicate cells with damaged (condensation and fragmentation) chromatin at the $48^{\text {th }}$ hour of incubation); $c$ - results of quantitative processing of results of DNA-comet analysis; $K, M, M+B, B, C-$ see Fig. 1 . $* * \mathrm{p} \leq 0,01 ; * * * \mathrm{p} \leq 0,001$

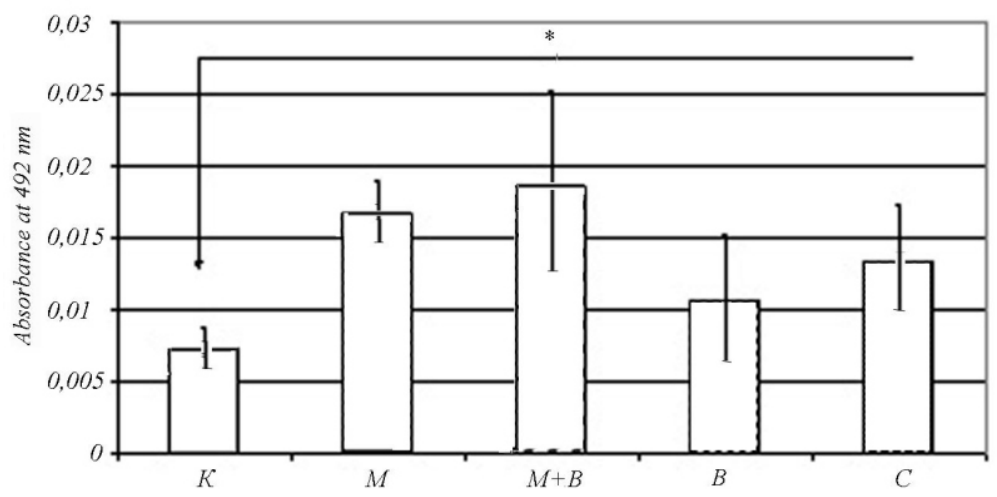

Fig. 5. Interaction of $\mathrm{IgG}$ obtained from different experimental groups, with DNA of calf thymus; $K, M, M+B, B, C$-see Fig. $1 ; * \mathrm{p} \leq 0,05$

cattle brain, are characterized by the highest ability of inducing necrosis accompanied by the outflow of LDH from the cells. In most variants of experiment, the manifestation of this activity increased with the duration of IgG effect on target cells. The presence of a considerable amount of necrotic cells that appeared due to the effect of IgG preparations, obtained from animals fed with cattle brain, was proven after staining test cells according to Romanovsky-Gimza. Fig. 7 shows cells with damaged plasma membrane that caused an outflow of cytoplasmic LDH from cells.

Thus, long-term feeding mice with products containing tissues of animals (in our case - brain), or products of their processing (meat-and-bone meal) results in producing antibodies of IgG class capable of inducing cell death due to necrosis. The presence of anti-DNA antibodies in the IgG preparations purified from blood serum of experimental animals, testifies to 


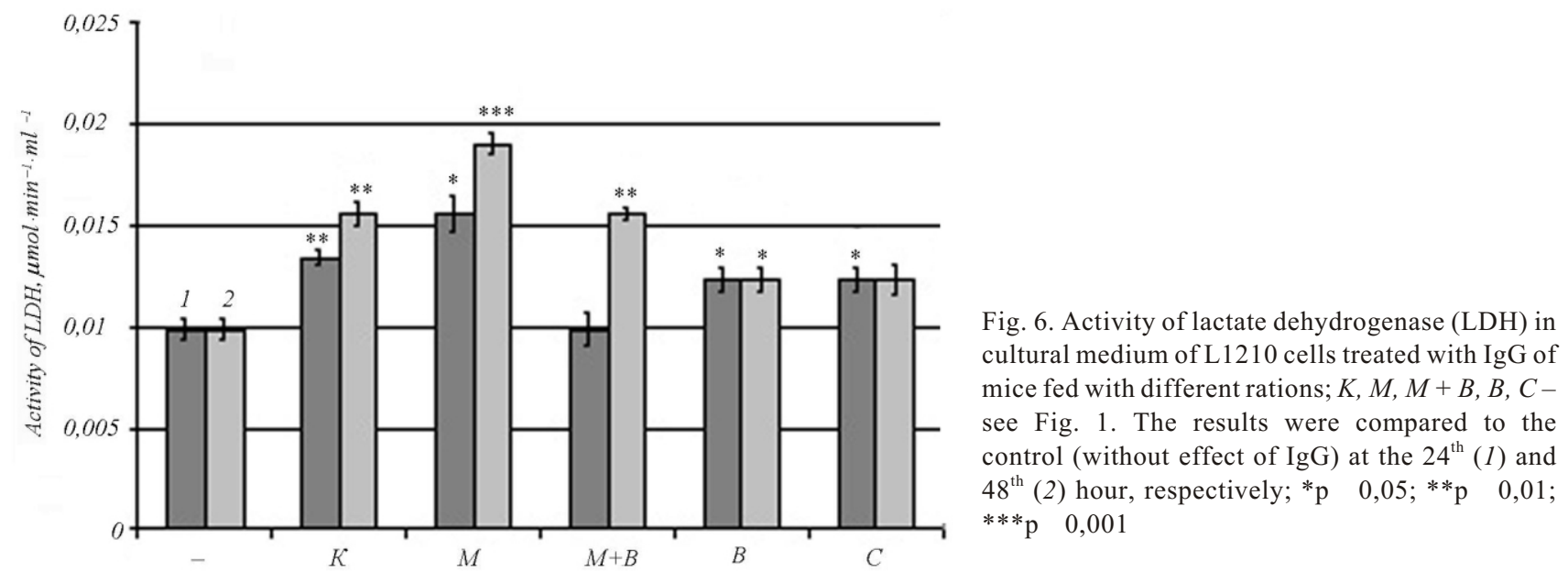

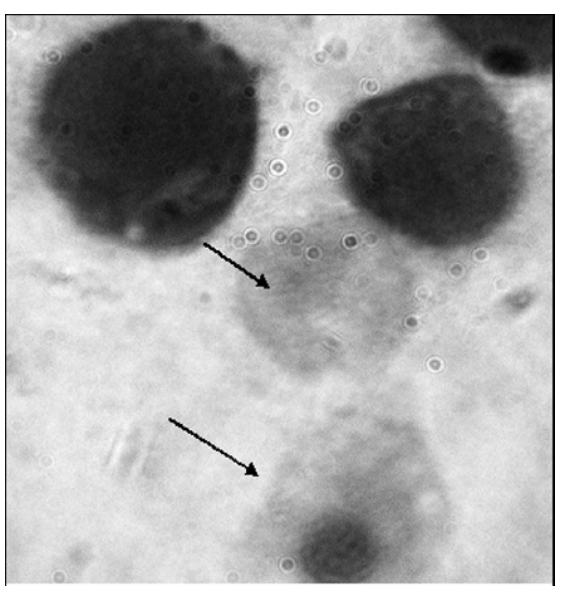

Fig. 7. Cells of L1210 line treated with IgG of mice fed with cattle brain. Staining was done according to Romanovsky-Gimza. Arrows indicate necrotic cells. 250 cells in different vision fields were calculated using microscope. Due to influence of $\mathrm{IgG}$ for 24 hours, the number of cells with features of necrosis in this experimental group equaled $24 \pm 5 \%$

the presence of autoimmune processes in their organism. Anti-DNA antibodies were determined to induce apoptosis in mammalian cells in vitro [12]. These data allow a supposition that an increase in the amount of cells with fragmented DNA due to the effect of IgG preparations of experimental animals may be related to proapoptotic activity of above mentioned antibodies. Though the nature of antibodies, capable of inducing cell necrosis in vitro, as well as the mechanism of their action towards these cells are yet not studied, it is possible to assume that their presence in the organism of experimental animals plays a significant role in the development of autoimmune processes. Oppositely to apoptosis, necrosis is characterized by the outflow of a considerable amount of intracellular proteins which are potential autoantigens in the extracellular space [23, 24]. In case of synergic action of foreign antigens that are structurally similar to these autoantigens, autoimmune tolerance of the organism may be damaged, which will result in development of autoimmune diseases. At the same time, it remains unclear why the highest level of such antibodies was revealed in animals that were fed with cattle brain. This fact could be related to the presence of a high number of lipids in brain tissues which might act as adjuvants in case of long-term feeding of experimental animals.

М. Р. Козак, В. В. Влизло, Ю. Я. Кит, Р. С. Стойка

Индукция апоптоза и некроза лейкемических клеток очищенными препаратами $\operatorname{IgG}$ сыворотки крови мышей, которым длительное время скармливали мозг крупного рогатого скота

Резюме

Исследовали свойства очищенных препаратов $\operatorname{IgG}$ мыщей. Установлено, что все препараты $\operatorname{IgG}$ мышей индуцируют гибель клеток линии L1210 лейкемии мыши. Наивыстий уровень ичттотоксической активности обнаружен при влиянии IgG мышей, которым дополнительно косновному рациону скармливали мозг крупного рогатого скота. Гибель тест-клеток происходила как вследствие апоптоза (характерные признаки - разрушение ДНК, обнаруженное методом комет ДНК, конденсация и фрагментация хроматина, выявленные флуоресиентной микроскопией после окрашивания клеток красителем Hoechst 33342), так и из-за некроза. Последний оценивали по уровню активности лактатдегидрогеназы, высвобождаемой из разрушенных клеток линии L1210 в культуральною среду, и световой микроскопией после окрашивания клеток по Романовскому-Гимза.

Ключевые слова: рацион, иммуноглобулины, иитотоксическая активность, апоптоз, некроз. 


\section{REFERENCES}

1. Axelrad $J$. An autoimmune response causes transmissible spongiform encephalopathies // Med. Hypotheses.-1998.50.-P. 259-264.

2. Engelstein R., Grigoriadis N., Greig N., Ovadia H., Gabizon $R$. Inhibition of P53-related apoptosis had no effect on $\operatorname{PrP}(\mathrm{Sc})$ accumulation and prion disease incubation time // Neurobiol. Dis.-2005.-18, N 2.-P. 282-285.

3. Giese A., Kretzschmar H. A. Prion-induced neuronal damage - the mechanisms of neuronal destruction in the subacute spongiform encephalopathies // Curr. Top. Microbiol. Immunol.-2001.-253.-P. 203-217.

4. Castilla J., Hetz C., Soto C. Molecular mechanisms of neurotoxicity of pathological prion protein // Curr. Mol. Med.-2004.-4, N 4.-P. 397-403.

5. Kuwata K., Matumoto T., Cheng H., Nagayama K., James T. $L .$, Roder $H$. NMR-detected hydrogen exchange and molecular dynamics simulations provide structural insight into fibril formation of prion protein fragment 106-126// Proc. Nat. Acad. Sci. USA.-2003.-100, N 25.-P. 1479014795.

6. Liberski P. P., Gajdusek D. C., Brown P. How do neurons degenerate in prion diseases or transmissible spongiform encephalopathies (TSEs): neuronal autophagy revisited // Acta Neurobiol. Exp.-2002.-62.-P. 141-147.

7. Marella M., Chabry J. Neurons and astrocytes respond to prion infection by inducing microglia recruitment // J. Neurosci.-2004.-24, N 3.-P. 620-627.

8. Andrievskaia O., McRae H., Elmgren C., Huang H., Balachandran A., Nielsen K. Generation of antibodies against bovine recombinant prion protein in various strains of mice // Clin. Vaccine Immunol.-2006.-1.-P. 98-105.

9. Zhu B. T. Human and animal spongiform encephalopathies are the result of chronic autoimmune attack in the CNS: a novel medical theory supported by overwhelming experimental evidence // Histol. Histopathol.-2005.-20.P. 575-592.

10. Ebringer A., Rashid T., Jawad N., Wilson C., Thompson E. J., Ettelaie $C$. From rabies to transmissible spongiform encephalopathies: an immune-mediated microbial trigger involving molecular mimicry could be the answer // Med. Hypoth.-2007.-68, N 1.-P. 113-124.

11. Paraf $A$. An immunological approach to prion diseases // Med. Hypoth.-1998.-50.-P. 85-90.
12. Lim P-L., Zouali M. Pathogenic autoantibodies: Emerging insights into tissue injury // Immunol. Lett.-2006.-103.P. 17-26.

13. Gabibov A. G., Ponomarenko N. A., TretyakE. B., Paltsev A., Suchkov $S . V$. Catalytic autoantibodies in clinical autoimmunity and modern medicine // Autoimmun. Rev.-2006.-5.-P. 324-330.

14. Иммунологические методы / Под ред. Г. Фримеля.-М.: Медицина, 1987.-390 с.

15. Laemmli $U$. K. Cleavage of structural proteins during the assembly of the head of bacteriophage T4 // Nature.-1970.-227.-P. 680-685.

16. Микроскопическая техника / Под ред. Д. С. Саркисова, Ю. Л. Петрова.-М.: Медицина, 1996.-544 с.

17. Chen Q., Liu W., Guo X., Li Y., Guo Z. Biphasic effect of aspirin on apoptosis of bovine vascular endothelial cells and its molecular mechanism // Acta Pharmacol. Sin.-2007.-28, N 3.-P. 353-358.

18. Руководство по лабораторным методам исследования / Под ред. Л. Г. Смирновой, Е. А. Кост.-М.: Медгиз, 1950.-23 c.

19. Камінський В. О., Луиик М. Д., Стойка Р. С. Аналіз фрагментації ДНК індивідуальних клітин методом гель-мікроелектрофорезу: модифікація фарбування солями срібла для одержання постійних препаратів // Укр. біохім. журн.-2005.-77, № 6.-С. 105-108.

20. Mori S., Watanabe $W$. A colorimetric LDH assay for the titration of infectivity and the evaluation of anti-viral activity against ortho- and paramyxoviruses // J. Exp. Med.-1995.-177.-P. 315-325.

21. Фільченков О. О., Стойка Р. С. Апоптоз і рак.-Тернопіль: Укрмедкнига, 2006.-523 с.

22. Wiegele G., Brandis M., Zimmerhackl L. B. Apoptosis and necrosis during ischaemia in renal tubular cells (LLC-PK1 and MDCK) // Nephrol. Dial. Transplant.-1998.-13.P. $1158-1167$.

23. Полетаев А. Б. Иммунологический гомункулус (иммункулус) в норме и при патологии // Биохимия.- 2002.-67, № 5.-С. 721-731.

24. Полетаев А. Б., Алферова В. В., Абросимова А. А., Комиссарова И. А., Соколов М. А., Гусев Е. И. Естественные нейротропные аутоантитела и патология нервной системы // Нейроиммунология.-2003.-1.-С. 11-17.

UDC 577.083.37:084.1:085.23 Received 20.04.07 